\title{
The effects of varied plant density and nitrogen fertilization on quantity and quality yield of Camelina sativa L.
}

\author{
Magdalena Czarnik, Wacław Jarecki ${ }^{*}$, Dorota Bobrecka-Jamro \\ Department of Crop Production, Faculty of Biology and Agriculture, University of Rzeszow, Zelwerowicza 4, 35-601 Rzeszów, Poland
}

\section{A B S T R A C T}

\begin{abstract}
False flax (Camelina sativa L.), is an oil plant, of the Brassicaceae (Cruciferae) family. It is a rediscovered crop with multiple uses, it is a frost proof, low-soil and climatic conditions plant. In Poland the variety is not very widespread, despite of its health benefits. The particular value of camelina oil is given by its content in polyunsaturated fatty acid (50-60\%), by its content in omega $3(35-40 \%)$ and by its content in omega $6(15-20 \%)$. The seeds are used for the extraction of oil (used in medicine or as bio fuel) or directly as animal feed. The research was carried out in the years 2012-2014 at the Experimental Station of Cultivar Assessment in Przecław, Poland. The summer Camelina sativa cv. 'Omega' was used for the experiment. The studied factors were: A-plant density (200, 300, 400 pcs. $\left.\mathrm{m}^{-2}\right)$ and B-nitrogen fertilization $\left(50,100 \mathrm{~kg} \cdot \mathrm{ha}^{-1}\right)$. With the increase of the sowing density significantly increased plant density after emergence and before harvest, but reduced the number of silicles per plant. Increase in the rates of sowing from 200 to $400 \mathrm{pcs}^{-2} \mathrm{~m}^{-2}$ decreased the 1000 seeds weight. Sowing 200 seeds $\mathrm{m}^{-2}$ compared to higher norms had significant effect on reduction the number of seeds in silicle, seed yield and the content of the seeds Fe, but resulted in an increase in the content of the seeds $\mathrm{Mn}$ and $\mathrm{Zn}$. On the other hand, sowing 400 seeds $\mathrm{m}^{-2}$ caused a reduction the protein in the seeds, $\mathrm{K}$, and $\mathrm{Mg}$, and an increase fat yield and crude fat content in seeds. The higher nitrogen dose significantly increased the number of silicles per plant, total protein content, Fe, $\mathrm{Zn}$ in the seeds, seed yield, yield total protein and the percentage of linoleic and linolenic acids, while reduced the number of seeds per silicle, the crude fat content in seeds and the percentage of oleic acid.
\end{abstract}

Keywords: Chemical composition; False flax; Fatty acids; Seed yield; Yield components

\section{INTRODUCTION}

Camelina sativa (L.) Crantz was cultivated in Poland for centuries, but now occupies a small area in Poland, due to the higher prevalence of yielding rape. There are two cultivated forms such as winter and summer, but the winter forms yielding higher than summer (Toncea, 2014; Mosio-Mosiewski et al., 2015). Martinelli and Galasso (2011) and Zanetti et al. (2017) claim that there are multiple environmental and agrotechnical benefits of camelina for eg.: small climatic and soil requirements. The seeds of camelina can be used universally, eg.: as feed (Steppa et al., 2017; Wang et al. 2017) and derived oil from them as food (Vollmann et al., 2007; Mińkowski et al., 2010) as well as technical oil, including biofuel (Karcauskiene et al., 2014; Mohammed et al., 2017). The nutritional value of oil is mainly due to a high content of unsaturated fatty acids, particularly n-3 (omega-3) fatty acids and multiple use values (Zubr and Matthäus 2002; Zubr, 2003a). It is appropriate to conduct further researches on the improvement of genetic traits of camelina (Vollmann et al., 2007) as well as the optimization agricultural technology. Gesch et al. (2017) as well as Koncius and Karcauskiene (2010) pay attention to the need of usage optimum sowing rate, which affects on plant habit and seed yield. An important agricultural treatment is also a mineral fertilization. Like other cultivated plants in the family Brassicaceae (Brassicaceae Burnett) false flax strongly respond to nitrogen fertilization (Solis et al., 2013; Jiang and Caldwell, 2016; Waraich et al., 2017).

The aim of this study was to estimate a reaction of the summer form of camelina to varied plant density and nitrogen fertilization. In the research hypothesis it was assumed that the varied plant density and nitrogen

\footnotetext{
${ }^{*}$ Corresponding author:

Wacław Jarecki, Department of Crop Production, Faculty of Biology and Agriculture, University of Rzeszow, Zelwerowicza 4, 35-601

Rzeszów, Poland, E-mail: waclaw.jarecki@wp.pl
} 
fertilization modifies evaluation parameters as well as quantity and quality yield of Camelina sativa [L.] Crantz.

\section{MATERIALS AND METHODS}

\section{Crop management}

The research was carried out in the years 2012-2014 in Przecław (The Experimental Station of Cultivar Assessment), south-eastern Poland (50 $\left.11^{\prime} \mathrm{N}, 2^{\circ} 29^{\prime} \mathrm{E}\right)$. It was a two-factorial experiment (split-plot) conducted in three replications. The experimental factors were: (A) plant density $\left(200,300,400\right.$ pcs. $\left.\mathrm{m}^{-2}\right)$ and (B) nitrogen fertilization $\left(50,100 \mathrm{~kg} \cdot \mathrm{ha}^{-1}\right)$. The breeder of summer Camelina sativa $\mathrm{cv}$. 'Omega' was Poznań University of Life Sciences, Poland. The experiment was set up on alluvial soils created from silt loam. The soil was classified in valuation class IIIb of the good wheat complex with $\mathrm{pH}$ slightly acid or inert in the range from 6.38 to 7.11 . Soil samples were collected by a sampling stick to a depth of $0-60 \mathrm{~cm}$. The content of available forms of phosphorus was high or very high, potassium - average or high, and magnesium - very high (Table 1). Soil analysis was carried out at the Chemical and Agricultural Station in Rzeszów, with generally accepted methods in Polish Stanards.

The data concerning weather conditions came from the Experimental Station of Cultivar Assessment in Przecław. From March to July in 2012 was the period in which the lowest total precipitation appeared. In May and June 2013 as well as in May and July 2014 high level of rainfalls was recorded and it exceeded considerably the long-term average (Table 2). During the plant growth higher air temperatures were noticed in 2012, and the lowest in 2014 (Table 3). Irrigation was not used in field trials.

The seeds of false flax were received from the Department of Genetics and Plant Breeding in Poznań University of Life Sciences. Oat was the forecrop of false flax in every year of research. The area of a plot was $7.5 \mathrm{~m}^{2}$, for harvesting $5 \mathrm{~m}^{2}$. The row spacing amounted to $15 \mathrm{~cm}$, and sowing depth $1.5 \mathrm{~cm}$. Seed dressed material was sown in three periods: 4.04.2012, 22.04.2013 and 24.03.2014. The sowing date was optimal for the area of the research. Under the autumn ploughing granular triple superphosphate (40 $\left.\mathrm{P}_{2} \mathrm{O}_{5} \mathrm{~kg} \cdot \mathrm{ha}^{-1}\right)$ and potash salt $\left(60 \mathrm{~K}_{2} \mathrm{O} \mathrm{kg} \cdot \mathrm{ha}^{-1}\right)$ were used. Nitrogen fertilization (34\% ammonium saltpeter) was applied in varied doses and terms (Table 4).

The herbicide Butisan SC $400\left(2.5 \mathrm{dm}^{3} \cdot \mathrm{ha}^{-1}\right)$ were applied after sowing. The secondary weed infestation was removed manually. The diseases and pests were not combated. Plant density per $1 \mathrm{~m}^{2}$ was calculated after emergence and before harvest. At the technical maturity stage, 20 representative plants were collected from each plot for determine yield
Table 1: Chemical characteristics of experimental soil

\begin{tabular}{lccc}
\hline Measurement & $\mathbf{2 0 1 2}$ & $\mathbf{2 0 1 3}$ & $\mathbf{2 0 1 4}$ \\
\hline Soil acidity (1 mol L KCl) & 6.38 & 7.11 & 7.00 \\
Humus (\%) & 1.92 & 1.84 & 1.72 \\
$\mathrm{~N}_{\min }$ 0-60 cm $\left(\mathrm{kg}^{\prime} \mathrm{ha}^{-1}\right)$ & 66.4 & 60.8 & 56.8 \\
$(\mathrm{mg} \mathrm{kg})^{*}$ & & & \\
$\mathrm{P}$ & 71.1 & 96.6 & 79.8 \\
$\mathrm{~K}$ & 153.6 & 175.9 & 160.2 \\
$\mathrm{Mg}$ & 72.4 & 66.9 & 60.9 \\
\hline
\end{tabular}

* - available forms

Table 2: Rainfall during the test crop cultivation (mm)

\begin{tabular}{lcccccc}
\hline Years & \multicolumn{5}{c}{ Months } & Total \\
\cline { 2 - 6 } & III & IV & V & VI & VII & \\
\hline 2012 & 27.8 & 21.7 & 66.7 & 66.9 & 65.6 & 248.7 \\
2013 & 73.6 & 39.4 & 111.7 & 192.4 & 58.3 & 475.4 \\
2014 & 49.6 & 34.8 & 108.9 & 69.0 & 146.8 & 409.1 \\
multi-annual & 35.9 & 48.1 & 39.2 & 79.3 & 101.6 & 304.1 \\
average & & & & & & \\
\hline
\end{tabular}

Table 3: Air temperatures during the test crop cultivation $\left({ }^{\circ} \mathrm{C}\right)$

\begin{tabular}{lcccccc}
\hline Years & \multicolumn{5}{c}{ Months } & Mean \\
\cline { 2 - 6 } & III & IV & V & VI & VII & \\
\hline 2012 & 3.9 & 9.9 & 14.7 & 18.2 & 20.9 & 13.5 \\
2013 & -1.3 & 8.8 & 15.0 & 18.5 & 19.4 & 12.1 \\
2014 & 5.4 & 8.8 & 13.3 & 15.1 & 19.4 & 12.4 \\
multi-annual average & 2.6 & 8.8 & 14.2 & 17.5 & 19.4 & 12.5 \\
\hline
\end{tabular}

Table 4: Fertilization diagram

\begin{tabular}{|c|c|c|}
\hline \multirow[t]{2}{*}{ Dose N (kg·ha-1) } & \multicolumn{2}{|c|}{ Application time, dose $\mathrm{N}\left(\mathrm{kg} \cdot \mathrm{ha}^{-1}\right)$} \\
\hline & Before sowing & BBCH (21) \\
\hline 50 & 50 & - \\
\hline 100 & 60 & 40 \\
\hline
\end{tabular}

components: a number of silicles per plant, a number of seeds per silicle and the 1000 seeds weight. Data regarding thousand seeds weight were recorded by counting randomly selected 1000 seeds from each plot and weighed with sensitive electronic balance. BBCH scale for false flax was given by Martinelli and Galasso (2011).

The harvest was conducted on the following dates: 18.07.2012, 29.07.2013 and 21.07.2014. The seed yield obtained from the plots was converted into yield per 1 ha, assuming a humidity of $15 \%$. The seed yield was adjusted for missing plants collected for biometric measurements. Total protein yield and crude fat were calculated from seed yield and percentage content of these components in seeds.

\section{Experimental design and treatments}

The content of total protein and crude fat in the seeds was determined with the NIRS method in near infrared on the apparatus Spectrometer FT NIR MPA Bruker (Billerica, USA). Macro- and microelements were developed at the University of Rzeszow (The Laboratory of the Faculty of 
Biology and Agriculture). To determine macroelements and microelements, plant samples were mineralized in a mixture of concentrated acids $\mathrm{HNO}_{3}: \mathrm{HClO}_{4}: \mathrm{HS}_{2} \mathrm{O}_{4}$ in the ratio 20:5:1, in an open system, in the heating block Tecator. In obtained mineralisates the contents of $\mathrm{Ca}, \mathrm{K}, \mathrm{Mg}, \mathrm{Zn}$, $\mathrm{Mn}, \mathrm{Cu}, \mathrm{Fe}$ were determined with atomic absorption spectroscopy (AAS), using the apparatus Hitachi Z-2000 (Tokyo, Japan), whereas P was determined with colorimetry, using the spectrophotometer UV-VIS Shimadzu (Kyoto, Japan), with the vanadium-molybdenum method. Analysis of fatty acids was performed using gas chromatograph Shimadzu's GC-17A (Kyoto, Japan) according to standards: PN-EN ISO 12966-4:2015-07.

\section{Statistical analysis}

The results were subjected to statistical analysis of variance. Calculations were made in the Statistica 8.0 programme (StatSoft, Tulsa, USA). Significance of differences between the means was indicated with the use of Tukey test, with a significance level of $\alpha=0.05$.

\section{RESULTS AND DISCUSSION}

\section{Yield and yield components}

Increasing the density of sowing resulted in a significant increase in plant density after emergence and before harvest (Table 5). In 2012, the plant density was the lowest impacted by low rainfall during the germination and plant emergence. Gesch et al. (2017) recommend that sowing should be not less than $3 \mathrm{~kg} \cdot \mathrm{ha}^{-1}$.

Nitrogen fertilization did not modify plant density. While Koncius and Karcauskiene (2010) obtained the diversity of the camelina plant density per $1 \mathrm{~m}^{2}$ with variable doses of NPK.

In own study, an increase the density of sowing significantly reduced the number of silicles per plant. The increase in nitrogen fertilization significantly increased the number of silicles per plant, an average of 9.1 psc. It confirmed the diversity of characteristics in years of the research.

Sowing 200 seeds $\mathrm{m}^{-2}$ compared to the sowing of 300 and 400 seeds $\mathrm{m}^{-2}$ contributed to the significant reduction in the number of seeds in silicle. The use of higher doses of nitrogen resulted in a significant decrease in the number of seeds in silicle. Increasing the amount of sowing seeds from 200 to 400 pcs. $\mathrm{m}^{-2}$ reduced the 1000 seeds weight (Table 5). The resulting difference was significant and amounted to an average of $0.18 \mathrm{~g}$.

The application of sowing seeds of 300 and 400 pcs. $\mathrm{m}^{-2}$ resulted in a significant increase in yield compared to 200 pcs. $\mathrm{m}^{-2}$. Seed yield was significantly higher with higher doses of nitrogen and the resulting difference as compared to the lower dose was $0.11 \mathrm{t} \cdot \mathrm{ha}^{-1}$. Between 2013 and 2014 the seed yield was significantly higher in relation to 2012.

Dobre et al. (2014) considered that plant density in spring should be over 350 pcs. $\mathrm{m}^{-2}$, which guarantees a high yield of seeds. The effect of higher doses of nitrogen on the growth of the yield was confirmed in previous studies by other authors (Jiang et al., 2013; Jiang et al., 2014; Sintim et al., 2015). For the optimal dose of nitrogen for false flax Jiang et al. (2013) reported 120 to $160 \mathrm{~kg} \cdot \mathrm{ha}^{-1}$. Afshar et. al. (2016) considered that higher doses than $45 \mathrm{~kg} \cdot \mathrm{ha}-{ }^{1}$ are not effective in growing camelina. Wysocki et al. (2013) said that

Table 5: Plant density, yield components and seed yield (average of years)

\begin{tabular}{|c|c|c|c|c|c|c|c|}
\hline \multicolumn{2}{|c|}{ Experience factor } & \multicolumn{2}{|c|}{ Number of plants } & \multirow{2}{*}{$\begin{array}{c}\text { Number of } \\
\text { silicles per } \\
\text { plant }\end{array}$} & \multirow{2}{*}{$\begin{array}{l}\text { Number of } \\
\text { seeds per } \\
\text { silicle }\end{array}$} & \multirow{2}{*}{$\begin{array}{c}1000 \text { seeds } \\
\text { weight } \\
(\mathrm{g})\end{array}$} & \multirow{2}{*}{$\begin{array}{c}\text { Seed } \\
\text { yield }\left(t \cdot h a^{-1}\right)\end{array}$} \\
\hline 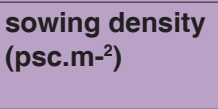 & $\begin{array}{c}\text { nitrogen } \\
\text { fertilization } \\
\left(\mathrm{N} \mathrm{kg} \cdot \mathrm{ha}^{-1}\right)\end{array}$ & $\begin{array}{l}\text { after emergence } \\
\left(\text { pcs. } \mathrm{m}^{-2}\right)\end{array}$ & $\begin{array}{l}\text { before harvest } \\
\left(\text { pcs. } \mathrm{m}^{-2}\right)\end{array}$ & & & & \\
\hline \multirow[t]{2}{*}{200} & 50 & 185 & 180 & 103.2 & 9.0 & 1.02 & 1.67 \\
\hline & 100 & 182 & 178 & 116.8 & 7.7 & 1.13 & 1.78 \\
\hline \multirow[t]{2}{*}{300} & 50 & 278 & 272 & 72.5 & 9.5 & 0.98 & 1.78 \\
\hline & 100 & 281 & 274 & 83.1 & 8.5 & 1.00 & 1.87 \\
\hline \multirow[t]{2}{*}{400} & 50 & 365 & 355 & 61.8 & 9.5 & 0.87 & 1.75 \\
\hline & 100 & 361 & 354 & 65.1 & 9.0 & 0.93 & 1.87 \\
\hline 200 & & $183.5^{c}$ & $179.0^{c}$ & $110.0^{\mathrm{a}}$ & $8.4^{b}$ & $1.08^{a}$ & $1.73^{b}$ \\
\hline 300 & & $279.5^{b}$ & $273.0^{b}$ & $77.8^{b}$ & $9.0^{\mathrm{a}}$ & $0.99 a^{b}$ & $1.83^{a}$ \\
\hline 400 & & $363.0^{\mathrm{a}}$ & $354.5^{\mathrm{a}}$ & $63.5^{c}$ & $9.3^{\mathrm{a}}$ & $0.90^{\mathrm{b}}$ & $1.81^{\mathrm{a}}$ \\
\hline 50 & & 276.0 & 269.0 & $79.2^{b}$ & $9.3^{a}$ & 0.96 & $1.73^{b}$ \\
\hline 100 & & 274.7 & 268.7 & $88.3^{a}$ & $8.4^{b}$ & 1.02 & $1.84^{\mathrm{a}}$ \\
\hline 2012 & & $269.5^{b}$ & $262.7^{b}$ & 83.3a $a^{b}$ & 8.82 & 0.96 & $1.69^{b}$ \\
\hline 2013 & & $276.8^{a}$ & $270.1^{a}$ & $86.4^{a}$ & 8.73 & 0.99 & $1.82^{\mathrm{a}}$ \\
\hline 2014 & & $279.8^{a}$ & $273.7^{a}$ & $81.5^{b}$ & 9.01 & 1.02 & $1.85^{\mathrm{a}}$ \\
\hline
\end{tabular}

Note. The mean marked by the same letter do not differ significantly 
the camelina requires about $12 \mathrm{~kg}$ of $\mathrm{kg} \cdot \mathrm{ha}-{ }^{1}$ per $100 \mathrm{~kg}$ of expected seed yield. Toncea (2014) reported that yield of camelina also depends on weather conditions and varieties.

\section{Chemical composition of seeds}

The increase in seeding rate to 400 pcs. $\mathrm{m}^{-2}$ resulted in reduction of the content in seed protein, and increased fat content and fat yield (Table 6). The higher dose of nitrogen in comparison to the lower contributed to an increase in seed content of protein and protein yield, and reduced crude fat content in seeds. In 2012 it was reported the highest total protein content in the seeds, and the lowest crude fat and fat yield.

Many authors (Jiang et al., 2013; Jiang et al., 2014; Sintim et al., 2015) confirmed that higher doses of nitrogen increase the protein content and lower fat content in the seeds of false flax. It has been shown that nitrogen fertilization increases protein yield (Jiang et al., 2013) and fat yield (Jiang et al., 2014). Zubr (2003b) as well as Zubr and Matthäus (2002) conclude that the differences in the quality of false flax seeds are mainly due to the varietal characteristics and conditions of climate and soil in which the plants were grown.

Applied the highest seed rate (400 psc. $\left.\mathrm{m}^{-2}\right)$ resulted in an increase in the content of the seeds $\mathrm{K}$ and $\mathrm{Mg}$. In turn, the plating 200 psc. $\mathrm{m}^{-2}$ increased the content in the seeds of $\mathrm{Mn}$ and $\mathrm{Zn}$ a decrease and of $\mathrm{Fe}$. Increasing the nitrogen fertilization with $50 \mathrm{~kg} \cdot \mathrm{ha}^{-1}$ to $100 \mathrm{~kg} \cdot \mathrm{ha}^{-1}$ increased the $\mathrm{Fe}$ and $\mathrm{Zn}$ content in seeds. In the study period content of $\mathrm{Fe}$ and $\mathrm{Zn}$ in seeds was varied (Table 7). The average macro- and micronutrient content in the seeds of false flax was different from given by Zubr (2010).

Varied sowing rates had no significant effect on the percentage of fatty acids. The higher dose of nitrogen in comparison to the lower increased the proportion of linoleic acid and linolenic acid and reduced oleic. Otherwise, it was proved that the contribution of certain fatty acids in the period was variable (Table 8). Jiang et al. $(2013,2014)$ showed that higher doses of nitrogen increase the percentage of polyunsaturated fatty acids, and reduce the percentage of monounsaturated fatty acids. Wang et al. (2017) reported that the camelina was rich in $\mathrm{C}_{18: 4, \mathrm{n}-3}$ and in $\mathrm{C}_{20} \mathrm{FA}$.

\section{CONCLUSIONS}

The agricultural practices, ie.: the sowing rates and nitrogen fertilization diversified yield components, yield and chemical composition in seeds of summer Camelina sativa $\mathrm{L}$.

The increase in the sowing density significantly developed plant density, but reduced the number of silicles per plant. Sowing 400 seeds $\cdot \mathrm{m}^{-2}$ resulted in a decrease of 1000 seeds compared to 200 seeds $\cdot \mathrm{m}^{-2}$. In turn, 200 seeds $\cdot \mathrm{m}^{-2}$ significantly decreased the number of seeds in the silicle, seed yield and content of $\mathrm{Fe}$ in the seeds. However, it increased the content of seeds in $\mathrm{Mn}$ and $\mathrm{Zn}$. It was found that the sowing of 400 seeds $\cdot \mathrm{m}^{-2}$ reduced the protein content in the seeds, $\mathrm{K}$ and $\mathrm{Mg}$, and increased the fat yield and crude fat content in the seeds. The higher nitrogen dose $\left(100 \mathrm{~kg} \cdot \mathrm{ha}^{-1}\right)$ significantly increased the number of silicles per plant, total protein content, $\mathrm{Fe}, \mathrm{Zn}$ in seeds, seed yield, protein yield and percentage of linoleic and linolenic acids. The lower nitrogen dose $\left(50 \mathrm{~kg} \cdot \mathrm{ha}^{-1}\right)$ increased the number of seeds in the silicle, the fat content in the seeds and the percentage of oleic acid.

The studies proved that spring summer Camelina sativa $\mathrm{L}$. reacts preferentially at the higher dose of nitrogen $(100 \mathrm{~kg}$ $\left.\cdot \mathrm{ha}^{-1}\right)$ and a higher sowing rates $\left(300-400 \mathrm{pcs}^{-2} \mathrm{~m}^{-2}\right.$.

Table 6: Seed content and yield total protein and crude fat (average of years)

\begin{tabular}{|c|c|c|c|c|c|}
\hline \multicolumn{2}{|l|}{ Experience factor } & \multirow{2}{*}{$\begin{array}{c}\text { Total protein } \\
\text { (\% DM) }\end{array}$} & \multirow{2}{*}{$\begin{array}{l}\text { Crude fat } \\
\text { (\% DM) }\end{array}$} & \multicolumn{2}{|c|}{ Yield $\left(\mathrm{t} \cdot \mathrm{ha}^{-1}\right)$} \\
\hline sowing density (psc. $\mathrm{m}^{-2}$ ) & nitrogen fertilization $\left(\mathrm{N} \mathrm{kg} \cdot \mathrm{ha}^{-1}\right)$ & & & total protein & crude fat \\
\hline \multirow[t]{2}{*}{200} & 50 & 27.3 & 29.4 & 0.46 & 0.49 \\
\hline & 100 & 28.4 & 28.2 & 0.51 & 0.50 \\
\hline \multirow[t]{2}{*}{300} & 50 & 27.0 & 29.8 & 0.48 & 0.53 \\
\hline & 100 & 27.7 & 28.5 & 0.52 & 0.53 \\
\hline \multirow[t]{2}{*}{400} & 50 & 26.1 & 31.2 & 0.46 & 0.55 \\
\hline & 100 & 26.9 & 30.6 & 0.50 & 0.57 \\
\hline 200 & & $27.9^{\mathrm{a}}$ & $28.8^{\mathrm{b}}$ & 0.48 & $0.50^{\mathrm{b}}$ \\
\hline 300 & & $27.4^{\mathrm{a}}$ & $29.2^{\mathrm{b}}$ & 0.50 & $0.53^{b}$ \\
\hline 400 & & $26.5^{\mathrm{b}}$ & $30.9^{a}$ & 0.48 & $0.56^{a}$ \\
\hline 50 & & $26.8^{\mathrm{b}}$ & $30.1^{\mathrm{a}}$ & $0.46^{\mathrm{b}}$ & 0.52 \\
\hline 100 & & $27.7^{\mathrm{a}}$ & $29.1^{\mathrm{b}}$ & $0.51^{\mathrm{a}}$ & 0.54 \\
\hline 2012 & & $29.3^{a}$ & $27.9^{b}$ & 0.50 & $0.47^{b}$ \\
\hline 2013 & & $26.6^{b}$ & $29.7^{a}$ & 0.48 & $0.54^{\mathrm{ab}}$ \\
\hline 2014 & & $25.8^{b}$ & $31.2^{\mathrm{a}}$ & 0.48 & $0.58^{a}$ \\
\hline
\end{tabular}

Note. The mean marked by the same letter do not differ significantly 
Table 7: The content of macroelement and microelement in seeds (average of years)

\begin{tabular}{|c|c|c|c|c|c|c|c|c|c|}
\hline \multirow{2}{*}{$\begin{array}{l}\text { Experience factor } \\
\text { sowing density (psc. } \mathrm{m}^{-2} \text { ) }\end{array}$} & \multirow{2}{*}{ nitrogen fertilization $\left(\mathrm{N} \mathrm{kg} \cdot \mathrm{ha}^{-1}\right)$} & $\mathbf{P}$ & $\mathbf{K}$ & $\mathrm{Ca}$ & $\mathrm{Mg}$ & $\mathrm{Fe}$ & $\mathrm{Cu}$ & Mn & Zn \\
\hline & & \multicolumn{4}{|c|}{ G kg DM } & \multicolumn{4}{|c|}{ mg kg DM } \\
\hline \multirow[t]{2}{*}{200} & 50 & 4.12 & 10.44 & 2.58 & 2.39 & 67.53 & 4.67 & 20.07 & 33.08 \\
\hline & 100 & 3.99 & 10.50 & 2.44 & 2.35 & 68.26 & 5.42 & 21.05 & 35.08 \\
\hline \multirow[t]{2}{*}{300} & 50 & 3.64 & 10.47 & 2.57 & 2.05 & 69.23 & 4.79 & 19.61 & 30.54 \\
\hline & 100 & 3.77 & 10.88 & 2.52 & 2.01 & 73.46 & 4.91 & 16.30 & 32.53 \\
\hline \multirow[t]{2}{*}{400} & 50 & 3.89 & 11.67 & 2.06 & 3.96 & 61.75 & 4.57 & 15.54 & 29.24 \\
\hline & 100 & 3.39 & 13.91 & 2.12 & 2.71 & 77.58 & 5.09 & 17.04 & 36.42 \\
\hline 200 & & 4.06 & $10.47^{b}$ & 2.51 & $2.37^{b}$ & $67.90^{\mathrm{b}}$ & 5.05 & $20.56^{a}$ & $34.08^{a}$ \\
\hline 300 & & 3.71 & $10.68^{b}$ & 2.55 & $2.03^{b}$ & $71.35^{\mathrm{a}}$ & 4.85 & $17.96^{b}$ & $31.54^{b}$ \\
\hline 400 & & 3.64 & $12.79^{a}$ & 2.09 & $3.34^{\mathrm{a}}$ & $69.67^{a}$ & 4.83 & $16.29^{b}$ & $32.83^{b}$ \\
\hline 50 & & 3.88 & $10.8^{6}$ & 2.40 & 2.80 & $66.17^{b}$ & 4.68 & 18.41 & $30.95^{b}$ \\
\hline 100 & & 3.72 & $11.7^{6}$ & 2.36 & 2.36 & $73.10^{\mathrm{a}}$ & 5.14 & 18.13 & $34.68^{a}$ \\
\hline 2012 & & 3.72 & 10.55 & 2.38 & 2.40 & $54.94^{c}$ & 4.75 & 17.07 & $30.80^{b}$ \\
\hline 2013 & & 4.04 & 11.60 & 2.33 & 2.32 & $69.07^{b}$ & 4.96 & 20.44 & $33.01^{a}$ \\
\hline 2014 & & 3.64 & 11.79 & 2.44 & 3.02 & $84.89^{a}$ & 5.02 & 17.30 & $34.63^{a}$ \\
\hline
\end{tabular}

Note. The mean marked by the same letter do not differ significantly

Table 8: Content of fatty acid (\%) in seeds (average of years)

\begin{tabular}{|c|c|c|c|c|c|c|c|c|}
\hline \multirow[t]{2}{*}{ Fatty acids } & \multicolumn{3}{|c|}{ Sowing density (psc. $\mathrm{m}^{-2}$ ) } & \multicolumn{2}{|c|}{ Nitrogen fertilization $\left(\mathrm{N} \mathrm{kg} \cdot \mathrm{ha}^{-1}\right)$} & \multicolumn{3}{|c|}{ Years } \\
\hline & 200 & 300 & 400 & 50 & 100 & 2012 & 2013 & 2014 \\
\hline Myristic C 14:0 & 0.06 & 0.07 & 0.07 & 0.06 & 0.07 & 0.07 & 0.06 & 0.07 \\
\hline Palmitic C 16:0 & 6.10 & 6.12 & 6.23 & 6.21 & 6.09 & 6.14 & 6.09 & 6.22 \\
\hline Palmitoleic C16:1 & 0.14 & 0.16 & 0.18 & 0.17 & 0.15 & 0.17 & 0.16 & 0.15 \\
\hline Stearic C 18:0 & 2.95 & 3.01 & 3.15 & 3.12 & 2.95 & $2.83 b$ & $3.34^{\mathrm{a}}$ & $2.94^{b}$ \\
\hline Oleic C18:1 & 16.56 & 17.47 & 17.52 & $19.55^{\mathrm{a}}$ & $14.81^{\mathrm{b}}$ & $19.80^{\mathrm{a}}$ & $16.65^{b}$ & $15.10^{\mathrm{b}}$ \\
\hline Linoleic C 18:2 & 18.53 & 18.72 & 18.91 & $15.65^{b}$ & $21.79^{a}$ & 18.90 & 19.01 & 18.25 \\
\hline Linolenic C $18: 3$ & 29.61 & 31.82 & 32.09 & $29.09^{b}$ & $33.27^{a}$ & $29.90^{c}$ & $32.12^{\mathrm{a}}$ & $31.52^{b}$ \\
\hline Arachidic C 20:0 & 1.76 & 1.92 & 1.98 & 1.99 & 1.78 & $1.88 \mathrm{~b}$ & $2.02^{\mathrm{a}}$ & $1.76^{c}$ \\
\hline Gondoic C 20:1 & 16.95 & 17.53 & 17.94 & 17.69 & 17.25 & $16.10^{b}$ & $16.84^{b}$ & $19.48^{a}$ \\
\hline Behenic C 22:0 & 0.37 & 0.43 & 0.46 & 0.44 & 0.40 & 0.42 & 0.45 & 0.39 \\
\hline Erucic C 22:1 & 3.75 & 3.81 & 3.91 & 3.93 & 3.72 & 3.61 & 3.77 & 4.09 \\
\hline
\end{tabular}

Note. The mean marked by the same letter do not differ significantly

\section{Authors' contributions}

Designed and conducted all of the experiment (M.Cz. and D.B.J). Collected data, data analysis, laboratory analysis (M.Cz. and W.J.). Statistical analysis of the data (W.J.) and wrote the manuscript (M.Cz. and W.J.). All authors have read and approved the final manuscript.

\section{REFERENCES}

Afshar, R. K., Y. A. Mohammed and C. Chen. 2016. Enhanced efficiency nitrogen fertilizer effect on camelina production under conventional and conservation tillage practices. Ind. Crop Prod. 94: 783-789.

Dobre, P., N. Farcaş, N. A. Udroiu, M. Gîdea and A. C. Moraru. 2014. Research on Camelina sativa wintering, by genotype and fertilizer doses used, in the pedo-climatical conditions from the south of Romania. Rom. Biotechnol. Lett. 19: 9964-9973.

Gesch, R. W., H. L. Dose and F. Forcella. 2017. Camelina growth and yield response to sowing depth and rate in the northern Corn Belt USA. Ind. Crop Prod. 95: 416-421.

Jiang, Y. and C. D. Caldwell. 2016. Effect of nitrogen fertilization on Camelina seed yield, yield components, and downy mildew infection. Can. J. Plant Sci. 96: 17-26.
Jiang, Y., C. D. Caldwell and K. C. Falk. 2014. Camelina seed quality in response to applied nitrogen, genotype and environment. Can. J. Plant Sci. 94: 971-980.

Jiang, Y., C. D. Caldwell, K. C. Falk, R. R Lada and D. MacDonald. 2013. Camelina yield and quality response to combined nitrogen and sulfur. Agron. J. 105: 1847-1852.

Karcauskiene, D., E. Sendzikiene, V. Makareviciene, E. Zaleckas, R. Repsiene and D. Ambrazaitiene. 2014. False flax (Camelina sativa L.) as an alternative source for biodiesel production. Zemdirbyste. 101: 161-168.

Koncius, D. and D. Karcauskiene. 2010. The effect of nitrogen fertilizers, sowing time and seed rate on the productivity of Camelina sativa. Zemdirbyste. 97(4): 37-46.

Martinelli, T. and I. Galasso. 2011. Phenological growth stages of Camelina sativa according to the extended $\mathrm{BBCH}$ scale. Ann. Appl. Biol. 158: 87-94.

Mińkowski, K., S. Grześkiewicz, M. Jerzewska and M. Ropelewska. 2010. Chemical composition profile of plant oils with high content of linolenic acids. Food. Sci. Technol. Qual. 6: 146-157.

Mohammed, Y.A., C. Chen, P. F. Lamb and R. K. Afshar. 2017. Agronomic evaluation of Camelina (Camelina sativa L. Crantz) cultivars for biodiesel feedstock. Bioenergy Res. 10: 792-799.

Mosio-Mosiewski, J., T. Łuczkiewicz, M. Warzała, J. Nawracała, H. Nosal and D. Kurasiak-Popowska. 2015. Study on utilization 
of Camelina seed for production of biodiesel fuel. Chem. Ind. 94: 369-373.

Sintim, H. Y., V. D. Zheljazkov, A. K. Obour, A. G. Garcia and T. K. Foulke. 2015. Influence of nitrogen and sulfur application on Camelina performance under dryland conditions. Ind. Crops Prod. 70: 253-259.

Solis, A., I. Vidal, L. Paulino, B. L. Johnson and M. T. Berti. 2013. Camelina seed yield response to nitrogen, sulfur, and phosphorus fertilizer in South Central Chile. Ind. Crops Prod. 44: 132-138.

Steppa, R., A. Cieślak, M. Szumacher-Strabel, S. Bielińska-Nowak, M. Bryszak, M. Stanisz and K. Szkudelska. 2017. Blood serum metabolic profile and fatty acid composition in sheep fedconcentrates with Camelina sativa cake and distillers dried grains with solubles. Small Ruminant Res. 156 (2017): 20-26.

Toncea, I. 2014. The seed yield potential of Camelia - first Romanian cultivar of Camelina (Camelina sativa L. Crantz). Rom. Agric. Res. 31: 17-23.

Vollmann, J., T. Moritz, C. Karg, S. Baumgartner and H. Wagentrist. 2007. Agronomic evaluation of Camelina genotypes selected for seed quality characteristics. Ind. Crops Prod. 26: 270-277.

Wang, S., M. Kreuzer, U. Braun and A. Scharm. 2017. Effect of unconventional oilseeds (safflower, poppy, hemp, Camelina) on in vitro ruminal methane production and fermentation. J. Sci. Food. Agric. 97: 3864-3870.

Waraich, E. A., Z. Ahmed, R. Ahmad, Saifullah, M. Shahbaz and Ehsanullah. 2017. Modulation in growth, development, and yield of Camelina sativa by nitrogen application under water stress conditions. J. Plant Nutr. 40: 726-735.

Wysocki, D. J., T. G. Chastain, W. F. Schillinger, S. O. Guy and R. S. Karow. 2013. Camelina: Seed yield response to applied nitrogen and sulfur. Field Crops Res. 145: 60-66.

Zanetti, F., C. Eynck, M. Christou, M. Krzyżaniak, D. Righini, E. Alexopoulou, M. J. Stolarski, E. N. Van Loo, D. Puttick and A. Monti. 2017. Agronomic performance and seed quality attributes of Camelina (Camelina sativa L. crantz) in multi-environment trials across Europe and Canada. Ind. Crop. Prod. 107: 602-608.

Zubr, J. 2003a. Dietary fatty acids and amino acids of Camelina sativa seed. J. Food Quality. 26: 451-462.

Zubr, J. 2003b. Qualitative variation of Camelina sativa seed from different locations. Ind. Crops Prod. 17: 161-169.

Zubr, J. 2010. Carbohydrates, vitamins and minerals of Camelina sativa seed. Nutr. Food Sci. 40: 523-531.

Zubr, J. and B. Matthäus. 2002. Effects of growth conditions on fatty acids and tocopherols in Camelina sativa oil. Ind. Crops Prod. 15: $155-162$. 